\title{
Looking for peace in the national curriculum of Mexico
}

\author{
Heather Kertyzia* - University for Peace, Costa Rica \\ Katerina Standish - University of Otago, New Zealand
}

\begin{abstract}
Schools are places where we can learn ways of being, seeing and living. They are transmission belts - social institutions that can engender values and attitudes from both how we learn and what we learn. Using content analysis, this mixed methods study assesses the national curriculum of Mexico - the Plan de Estudios Educación Básica, 2011 - for three components found in peace education programmes: recognizing violence (direct, structural or cultural); addressing conflict nonviolently; and creating the conditions of positive peace. These three components contribute to the analysis of the Sustainable Development Goals (SDGs): quality education (SDG 4); gender equality (SDG 5); reduced inequalities (SDG 10); responsible consumption and production (SDG 12); and peace, justice and strong institutions (SDG 16). This component of the Peace Education Curriculum Analysis (PECA) Project finds that the Plan de Estudios contains limited content that recognizes violence, some evidence of techniques used in transforming conflict nonviolently and only select content that is concerned with contributing to positive peace.
\end{abstract}

Keywords: peace education; content analysis; Mexico; curriculum; PECA Project

\section{Introduction}

In 2012, rising violence in Mexico forecast significant consequences for students. The escalating violence in the country looks to have severe economic and social impacts in both the short and long term. In terms of education, violence leads to lower academic performance by increasing students' stress levels, lowering attendance rates and causing students and teachers to migrate away from dangerous communities and sometimes out of the country. (Magaloni, 2012: para. 2)

Mexico has long been struggling with violence, whether in relation to drugs, gangs, domestic violence or cultural discrimination, and observers have noted a 'sharp increase in violence' (Márquez-Padilla et al., 2015: 2) since 2007; the 'number of homicides per 100,000 inhabitants almost tripled between 2005-2011' (Márquez-Padilla et al., 2015: 6). Not only does the violence impact students' access to education and their levels of achievement, but also schools become loci of conscription as 'schoolyards have become recruiting grounds for gangs', drawing whole communities into 'the volatile and exceedingly violent world of organized crime' (Lozano Garza, 2015: 200). In September 2014, 43 students of the Rural Teachers' College of Ayotzinapa, in the state of Guerrero disappeared. Two months later, a mass grave was found in Cocula, Guerrero that was said to contain the remains of students who were 'kidnapped, 
killed, burned and thrown in the river' (BBC News, 2015: n.p.; Perez, 2014). With the environmental climate of violence present in Mexico, one might ask how education itself performs as a space that challenges rather than perpetuates the violence that students might find themselves exposed to.

This study seeks to explore school in Mexico not only as a space that can potentially promote violence, but also as a location that can teach peace. School is made up of different aspects, including the individual, the social context and educative partners that can include teachers, students, parents and the greater community. Public schools in Mexico operate with one national curriculum, despite regional and cultural differences, as all Mexican public schools follow one guiding document. It is important to analyse how the national curriculum of Mexico approaches concepts such as violence and peace, and to investigate to what extent the curriculum incorporates content conducive to positive peace. In the following mixed methods study, the national curriculum of Mexico - the Plan de Estudios Educación Básica, 2011 (Secretaría de Educación Pública, 2015) - is examined for three components routinely found in peace education programmes: recognizing violence (direct, structural or cultural); addressing conflict nonviolently; and creating the conditions of positive peace.

\section{Peace education}

Peace education utilizes pedagogy for personal transformation. Peace education theory links 'violence in learning' to 'violence in society'. Therefore, peace pedagogy (teaching by peace) is concerned with creating attitudes, behaviours and perceptions that permit students to recognize violence, transform conflict nonviolently and contribute to positive peace (Galtung, 1996; Boulding, 2000; Ocejo and Hernández Romano, 2016). Peace education, like global education, can be used as an umbrella term to describe education that 'opens people's eyes and minds to the realities of the world, and awakens them to bring about a world of greater justice, equity and human rights for all' (Maastricht Global Education Declaration, 2002: 2). Schools are cultural establishments, and social disparity in schools can lead to concrete cultural and environmental disadvantages outside school. Peace education recognizes that schools do not have to be sites that transmit violence and inequality, but can be locations that are committed to personal change and altering patterns of cultural dominance (Carter and Vandeyar, 2009; Abrego Franco, 2010; Amador Hernandez, 2008). 'One of the common elements that unite scholars and practitioners who claim membership in the field of peace education is optimism that education can lead to positive social change' (Bajaj, 2008: 3). Looking at national curricula as spaces that potentially lead to peace means understanding how peace education is different.

Peace education is orientated to the awareness and preservation of human rights, as well as other goals such as environmental consciousness and the pursuit of social justice (Harber and Sakade, 2009; Fisas, 2011). Peace education has a direct relationship with the United Nations Sustainable Development Goals (SDGs) as it is also concerned with quality education (SDG 4), gender equality (SDG 5), reduced inequalities (SDG 10), responsible consumption and production (SDG 12) and peace, justice and strong institutions (SDG 16). The techniques, principles and cultural standards that are transmitted in education form the distinction between normal (nonpeace) education and peace education.

Normal education is often orientated towards satisfying the needs of a society, and it is geared towards creating compliant citizens and productive contributors to the social world (Harber and Sakade, 2009). Peace education, in comparison, is a 
personally transformative process that impacts the individual student first and society second. And although past research has sought to investigate the consequences of education for peace programmes in various locales (Duffy, 2000; Clarke-Habibi, 2005; Salomon, 2004; Danesh, 2010; Bar-On, 2010; Lozano Garza, 2015), this study is the first of its kind to analyse non-peace education for peace education qualities.

\section{Curricular statements as documentary evidence}

This study investigates the Mexican national curricular statement for peace education qualities. Curricular statements represent the end product of a process undertaken by curricular stakeholders that become repositories (documents) for the values or attitudes that stakeholders have agreed upon when selecting criteria for inclusion in education - curricular statements show empirical evidence both of what is included and of what is excluded from the curriculum that is ultimately arrived at. Curricular statements are 'textual statements regarding curricula that refer to intended outcomes, learner experiences, and understandings about the goals and objectives of learning' (Standish, 2015: 179-80).

As cultural products, curricular statements provide concrete documentary evidence of what ideas, opinions and perspectives are considered important during the selective process of creating school curricula. National curricular statements encompass particular meanings 'produced by someone to have meanings for someone else' (Krippendorff, 2004: 19), and they speak to wide-ranging standards and objectives that a nation should uphold and obtain. By analysing curricular statements for three peace education qualities, this study can confidently determine which values are present during the manifestation of these texts in relation to peace education and, ultimately, determine if the national curriculum of Mexico is educating for peace.

\section{Defining peace education}

There are emerging characteristics of how peace education is defined. The United Nations Children's Fund (UNICEF) states that peace education is:

the process of promotoing the knowledge, skills, attitudes, and values needed to bring about behaviour changes that will enable children, youth and adults to prevent conflict and violence, both overt and structural; to resolve conflict peacefully; and to create the conditions coducive to peace. (Fountain, 1999: 1)

This analysis modifies the UNICEF principles as follows: preventing violence is understood to mean the recognition of violence (prevention is not possible without prior acknowledgment), resolving conflict peacefully is established in this study as resolving conflict without violence and building the conditions conducive to peace is comprehended by the Peace Education Curriculum Analysis (PECA) Project as representing conditions that contribute to positive peace (as opposed to negative peace).

\section{The PECA Project}

This study is a part of the PECA Project, a continuing and evaluative study that assesses existing curricular statements for three elements commonly found in peace education (Standish, 2015, 2016; Standish and Kertyzia, 2014; Standish and Joyce, 
2016; Standish and Talahma, 2016; Standish and Nygren, 2018). This project is the first analysis of its kind and aims to stimulate conversations about mainstream education and peace education. The PECA Project looks only at curricular documents and does not evaluate peace education practice or programmes that might happen outside the curricular document. The PECA Project (www.pecaproject.org) is a peace research profile that aims to contribute to worldwide interdisciplinary academic relationships and is committed to academic transparency.

\section{Conceptual framework}

Along the lines of the aforementioned UNICEF definition, and incorporating the PECA Project adjustments, this research explores curricular statements to investigate the presence or absence of three elements common in peace education.

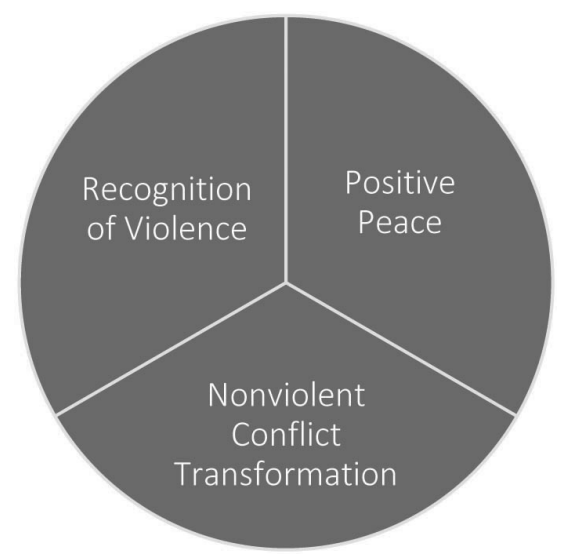

Figure 1: Conceptual framework of the PECA Project

Similar to other national analyses conducted in the PECA Project (Standish, 2016; Standish, 2015; Standish and Kertyzia, 2014), this article assesses the Mexican national curricular statement for recognition of violence, nonviolent conflict transformation methods, and nine aspects of positive peace. These three categories are also represented in the Mexican literature regarding peace education (Ruiz León, 2013; Gómez Collado, 2010). Positive peace is considered to be the absence of both direct and structural violence, whereas negative peace refers to an absence of only direct violence, as in a cessation of violence that may result from a peace treaty (Galtung, 1990). Positive peace is the presence of justice and equity (Ocejo and Hernández Romano, 2016: 81).

\section{Methodology}

This mixed methods investigation of the Mexican national curricular statement incorporates quantitative and qualitative data in the analysis (Mertens, 2010). Through the employment of both directive and summative content analysis (Hsieh and Shannon, 2005), the document comprising the curricular statement of Mexico was analysed to identify the frequency (summative) and semantic meaning (directive) of textual passages (passages are composed of either sentence, bullet or heading segments) from an existing list of elemental properties (see Table 1). The content analysis locates incidences of content related to these elements and the frequency of such incidences. 


\section{Table 1: Three elements of peace education}

Element One: recognition of violence

Element Two: nonviolent conflict transformation

\section{Element Three:} positive peace
In this study, violence is considered to be an intentional, harmful and avoidable human behaviour. Three forms of violence are considered in this element: violence that is part of a world view (cultural); violence that is a social process (structural); and violence that is an incident (direct).

Peace education theory holds that conflict should be transformed nonviolently. This implies, for instance, that a conflict that is transformed using weapons cannot contribute to a nonviolent outcome, as violence was utilized to acquire the eventual outcome. In the context of this research profile, we code for nonviolent conflict transformation tools such as dialogue, mediation, negotiation and collaboration, even when they are not utilized in the specific practice of transforming conflict.

1. Peace zone: safe spaces where violence is absent

2. Peace bond: positive relationships characterized by kindness and empathy

3. Social justice: fairness, equality and/or human rights

4. Eco mind: harmonious living between humanity and nature

5. Link mind: perception of interconnectivity and/or interdependency

6. Gender mind: awareness of gender as an important facet of understanding

7. Resilience: ability to absorb calamity - personal, social or environmental

8. Well-being: health, wellness and taking responsibility for self or others

9. Prevention: knowing ways to stop violence before it starts.

Source: Standish and Kertyzia (2014: 78)

Content analysis is a widely used methodology that systematically assesses documentary evidence using persistent engagement (often utilizing computer software) to identify various aspects (Krippendorff, 2004) from a text (or other documentary components) in a replicable and compressive technique. The outcome of a content analysis is a concise appreciation of large quantities of data in an accessible form. The summative data in this analysis were extracted using NVivo 11 analytical software, and the directive data in this analysis were thematically analysed using qualitative data analysis (QDA), whereby themes in the data are identified and distinguished through repeated and triangulated assessment (Leedy and Ormrod, 2001). Repeated engagement involves repetitive analysis of text to determine extant empirical content (words or phrases), and the findings are then triangulated (assessed from a different point of view) using, at minimum, two human coders.

\section{Data}

This analysis involves a comprehensive investigation of the Mexican national curriculum entitled Plan de Estudios: Educación Básica Primaria 2011, henceforth referred to as Plan de Estudios. The document under review in this research was obtained from the Government of Mexico's Secretary of Public Education and accessed online (Secretaría de Educación Pública, 2015). 


\section{Mexico and the Mexican curriculum}

Mexico (the United Mexican States) is a country inhabited by Mesoamericans encompassing a variety of indigenous groups, migrants and the descendants of the Spanish Imperial conquest. Mexico is the most northern border of Latin America, located south of the United States, north of Guatemala and Belize, with the Pacific Ocean and Caribbean Sea on its western and eastern shores respectively. Mexico has a population of almost 130 million people, and her current national borders were established in 1853 as a former Spanish colony.

The Mexican curriculum is separated into preschool (ages 1 to 5 - Programa de Educación Preescolar), primary (ages 6 to 11 - Educación Básica Primaria) and secondary education (ages 12 to 18 - Educación secundaria). As the early childhood (preschool) and secondary curricula are currently under development, it is the basic education statement (that encompasses both primary and secondary schooling) that is analysed here - the Educación Básica Primaria Plan de Estudios, 2011.

\section{Findings}

This section presents evidence of the empirical study that assessed the Mexican basic curriculum in regard to three peace education elements. Element One presents passages that contain content that refer to cultural, structural and direct forms of violence. Element Two presents text that shows content communicating methods or techniques that are used when transforming conflict nonviolently. Element Three shows evidence from the Mexican curriculum that relates to the nine categories that contribute to positive peace, previously mentioned (see Table 1). In alignment with data presentation in the rest of the PECA Project, each element is illustrated with a graphic representing the explanatory statistics derived from the analysis, as well as exemplary quotations from the curriculum in English. (The numbers in parentheses refer to the page number of each quotation. The Spanish original and the English translations are provided in the Appendix. The translations into English were made by one of the authors, Dr Heather Kertyzia, who holds a degree in Hispanic studies and is fluently bilingual.)

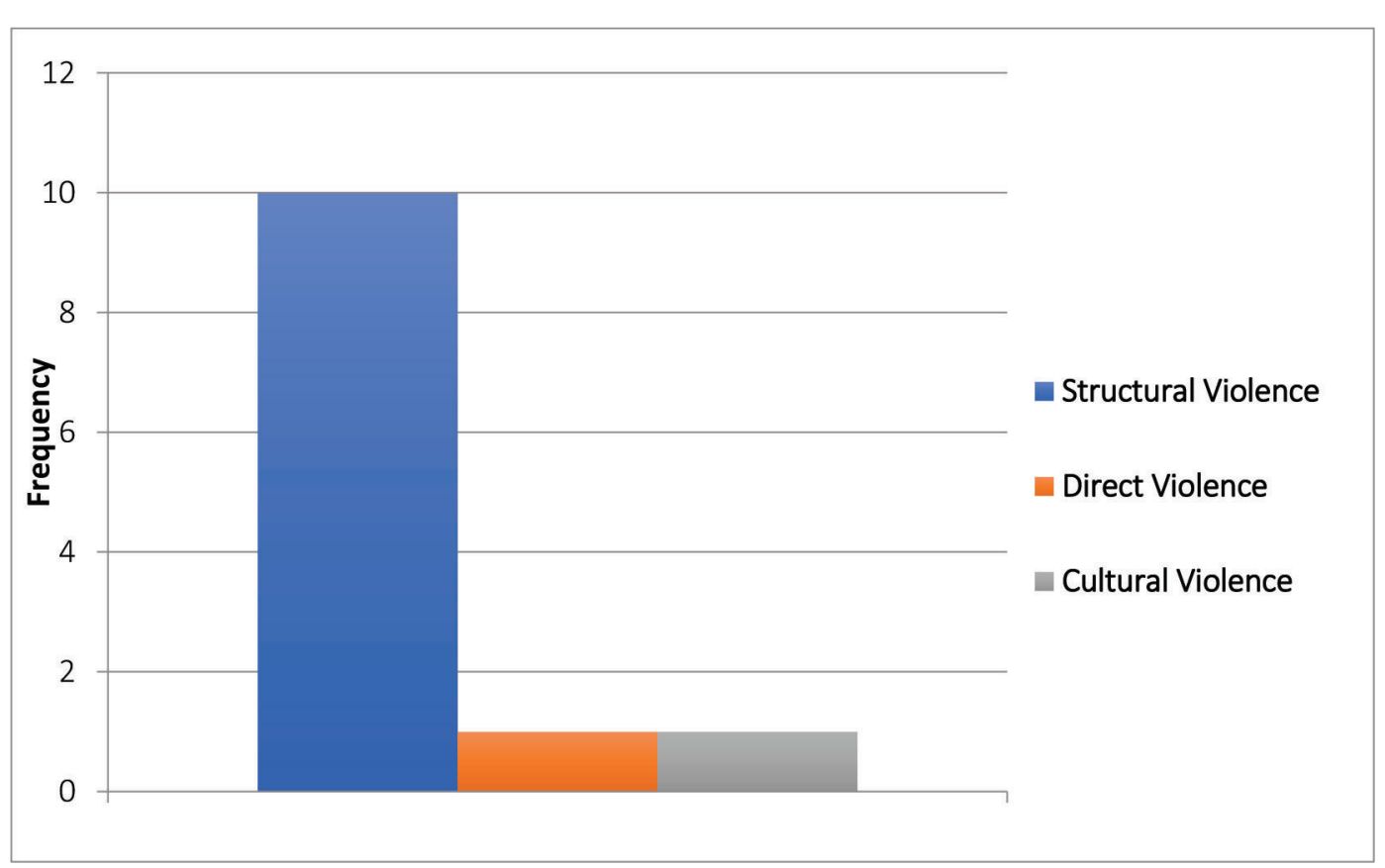

Figure 2: Element One - Recognition of violence in Plan de Estudios (2011) 
In order to meet SDG targets 16.1 (Significantly reduce all forms of violence and related deaths everywhere), 16.2 (End abuse, exploitation, trafficking and all forms of violence against and torture of children) and 5.2 (Eliminate all forms of violence against all women and girls in the public and private spheres, including trafficking and sexual and other types of exploitation), the first step is to recognize violence in all of its forms, and, specifically for SDG 16.2 and SDG 5.2, make children aware that differing forms of violence exist and are unacceptable.

The Plan de Estudios mentions direct violence once, structural violence ten times and cultural violence once. The single passage recognizing direct violence refers to the prevention of school violence (bullying) (36). Structural violence is recognized in relation to social hierarchies $(34,35)$, gender inequality (34), discrimination against persons with a disability $(35,38)$, combating discrimination and racism (in particular against indigenous cultures or languages) $(39,47,58)$, and access to information and technology $(64,68)$. In section 1.8 of the curriculum, with regard to inclusion and diversity, the Plan de Estudios states: 'Education is a fundamental right and a strategy to amplify opportunities, orchestrate intercultural relations, reduce inequalities between social groups, close gaps and drive equity' (35). Cultural violence is mentioned generally once, in the context of the fight against discrimination and racism (39).

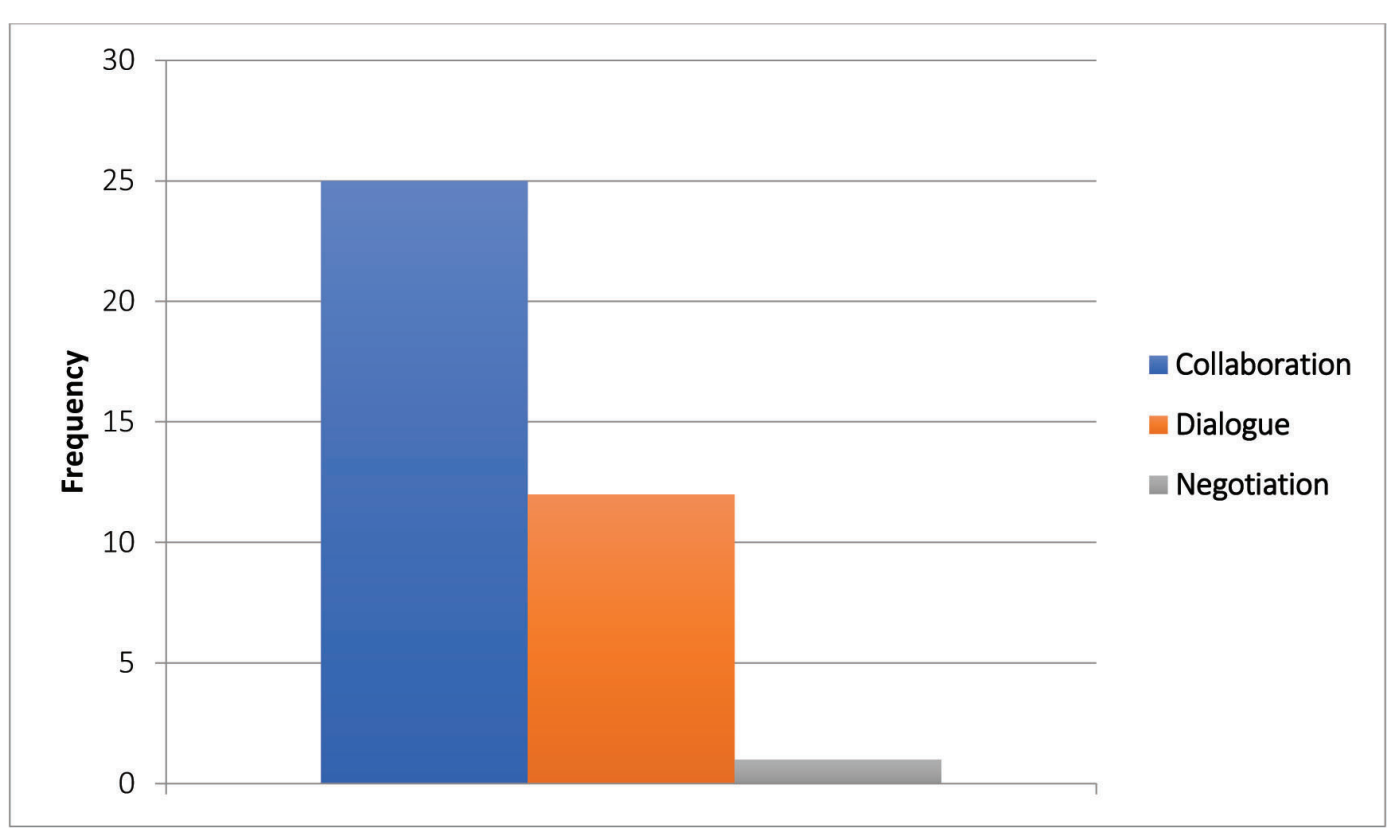

Figure 3: Element Two - Nonviolent conflict transformation tools in Plan de Estudios (2011)

The most common conflict transformation technique mentioned in the Plan de Estudios is collaboration ( $N=25)$, followed by dialogue $(\mathrm{N}=12)$ and negotiation $(\mathrm{N}=1)$. Collaboration is discussed in relation to working in collaborative networks $(10,19,22$, 69), to 'establish academic learning networks in which all the members of the school community participate' (18); to collaborate in class $(5,26,27,28,30,36,40,47,66$, 89), such that 'the learning of each student and of the group is enriched by social and cultural interaction ... in an environment of respectful and collaborative work' $(25,26)$; and in support of collaboration within communities $(53,69)$ :

The Comprehensive Reform of Basic Education (CRBE) requires for its effective application that the school collectives develop new ways of 
relating, collaborating and organizing, since each school represents in itself a space for learning and, at the same time, forms part of a network of learning governance comprised of teachers, students, and parents, among the other community actors. (69)

The need for, or appreciation of, dialogue is referred to multiple times $(9,26,37,56,63$, $87)$, and the practice of dialogue is referred to as varied (63). Negotiation (38), which is a part of the competencies to be developed at all levels of basic education, is included in competencies for coexistence as 'negotiate with others' (38).

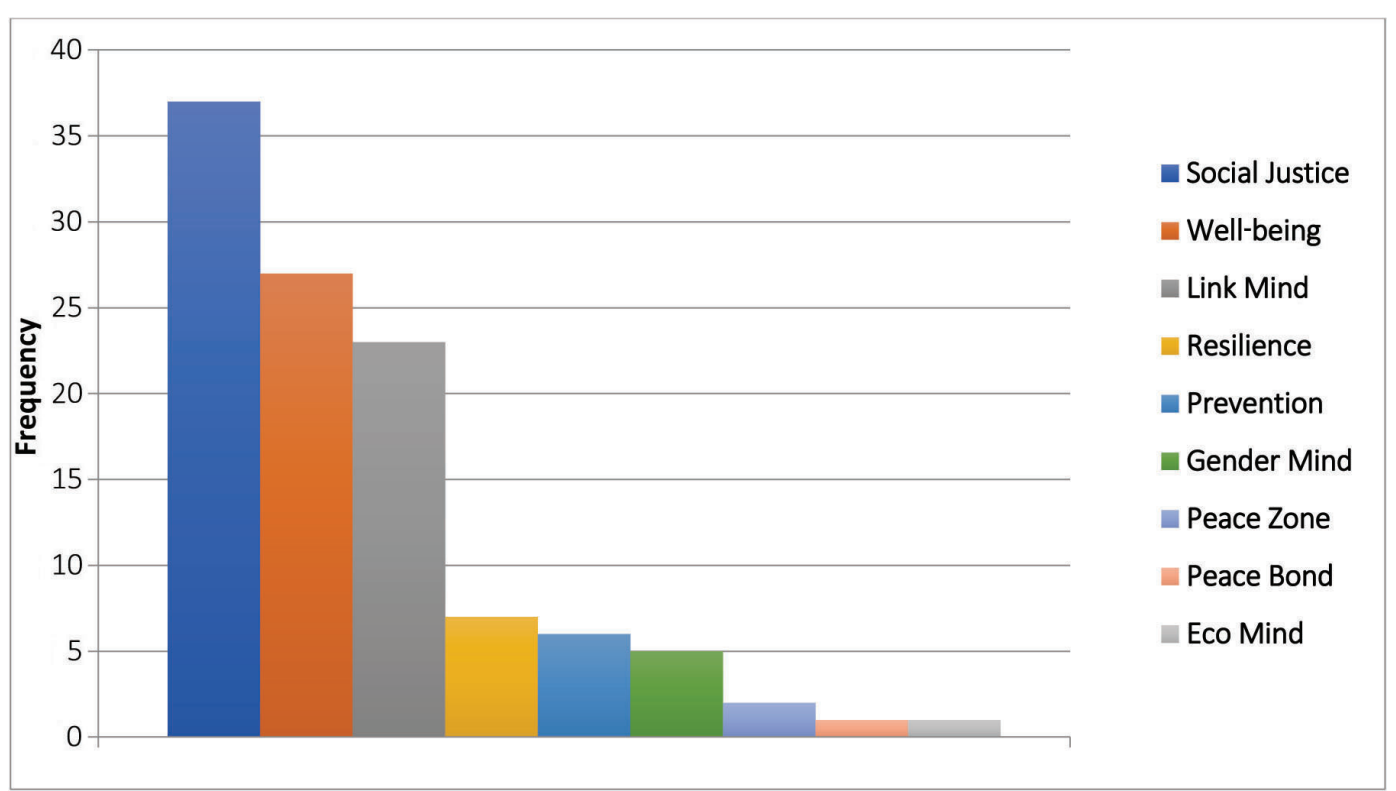

Figure 4: Element Three - Positive peace elements in Plan de Estudios (2011)

All facets of positive peace are mentioned in the Plan de Estudios, although with varying levels of explanation and perceived importance. The most common element is social justice $(N=37)$, followed by well-being $(N=27)$, link mind $(N=23)$, resilience $(N=7)$, prevention $(N=6)$, gender mind $(N=5)$, peace zone $(N=2)$, eco mind $(N=1)$ and peace bond $(\mathrm{N}=1)$, and PECA positive peace nodes congruent with the SDGs include social justice, well-being, gender mind, eco mind and prevention.

By discussing social justice themes in the curriculum, countries contribute to SDG targets 10.2 (By 2030, empower and promote the social, economic and political inclusion of all, irrespective of age, sex, disability, race, ethnicity, origin, religion or economic or other status) and 10.3 (Ensure equal opportunity and reduce inequalities of outcome, including by eliminating discriminatory laws, policies and practices and promoting appropriate legislation, policies and action in this regard). Curricular documents are government policies that can promote social justice.

The broad themes that relate to the positive peace facet of social justice - fairness or equality - refer to inclusion, diversity, human rights and indigenous rights. Inclusion often particularly mentions students with disabilities $(5,17,21,35)$ or indigenous rights and the inclusion of indigenous knowledge $(57,60,61,63)$. For example, the CRBE requires that education 'favour inclusive education, in particular local expression, the linguistic and cultural plurality of the country, and students with special educational needs, with or without disabilities' (17). A major theme throughout is respect for, and the value of, diversity $(11,19,25,26,27,35,36,38,40,46,47,50)$; for instance, 'Mexican 
society in the twenty-first century is the result of the fusion or convergence of diverse cultures, all valuable and essential' (11). Human rights are broadly mentioned (16, 35, $36,38,39,53,54)$; for example, 'basic education is responsible for creating scenarios based in human rights and respect for human dignity' (35).

Coding of well-being includes psychosocial well-being, as referenced in SDG indicator 4.2.1 (Proportion of children under 5 years of age who are developmentally on track in health, learning and psychosocial well-being, by sex). Well-being - health, wellness and taking responsibility for self or others - in this curriculum can generally be divided into textual references that refer to physical development and health $(6,16,17$, $22,23,36,40,41,50,51,53,55,69,77,79)$, for example, 'health promotion (nutrition and the prevention of addictions, et cetera)' (23), personal safety $(17,22,66,69,72)$, 'the prevention of burns and other accidents' (51), social and/or emotional development $(12,18,41,44,54,60,62)$ and 'the construction of personal identity and of social and emotional competencies' (54).

Curricula that have a focus on gender mind contribute to SDG indicator 5.1 (End all forms of discrimination against all women and girls everywhere) and demonstrate 5.c (Adopt and strengthen sound policies and enforceable legislation for the promotion of gender equality and the empowerment of all women and girls at all levels). Of the five gender mind references - where gender is considered an important element of understanding - three relate to gender equity $(13,22,36)$ (for example, 'each one of the actions and curricular plans is directed at strengthening gender equity' (13)), the promotion of 'respect between genders' (57) and 'parameters related to social or gender hierarchies' (34).

Curricular documents that demonstrate eco mind contribute to SDG target 12.8 (By 2030, ensure that people everywhere have the relevant information and awareness for sustainable development and lifestyles in harmony with nature), and indicator 12.8.1 directly measures this in curricula. Eco mind - harmony between humanity and nature - was coded one time in a segment communicating the importance of 'relating harmoniously with others and nature' (38).

Curricula that specifically discuss and mandate the prevention of violence contribute to SDG target 16. a (Strengthen relevant national institutions, including through international cooperation, for building capacity at all levels, in particular in developing countries, to prevent violence and combat terrorism and crime). Prevention - stopping violence before it starts - is found in text that refers to impeding forms of discrimination $(35,36,39,47)$; for example, use 'practices that reject discrimination' (47). Prevention of school violence (36) was previously discussed in the recognition of violence section, in relation to bullying prevention. Finally, there is a mention of the possibility of harm to individuals through school policy (36). The Plan de Estudios explains: 'it is advisable that the rules of the classrooms and of the school are revised periodically, in order to determine which are functional, do not harm anyone and support joint work' (36).

The final four positive peace nodes found in this curriculum are link mind, peace bond, resilience and peace zone. Link mind - the awareness of the interconnectivity and interdependence of living beings - is well documented in this curriculum. In particular, the positive peace facet of link mind was expressed regarding the relationship between students, parents, teachers and the community $(8,9,15,18,20,28,31,36,37,69)$, as previously referenced in the findings relating to collaboration. There were references to an interconnected world and individuals $(10,12,56)$ (for example, 'a world that is increasingly more interrelated' (10)), and to interconnected community and school networks $(17,18,30,57,60,66,67,71)$ (for example, 'a school of the community where everyone grows individually and collectively: students, teachers, parents' (17)). 
Content that represents the positive peace facet peace bond must refer to positive relationships characterized by kindness and empathy. Although the Plan de Estudios contains several passages that refer to 'harmonious' relationships $(38,53,54$, 69), only one segment of text was coded as peace bond by specifically mentioning empathy (38). In competencies for coexistence, it states that their development promotes 'empathy, to relate harmoniously with others and nature' (38). Resilience the ability to cope with misfortune - is communicated when students are encouraged to face and overcome problems and situations of risk $(9,31,38,40,53,57,69)$, including 'opportunities to face with better success the challenges of the present and future' (9). Peace zone (safe spaces where violence is absent) was found twice, present in the document as 'safe spaces', implying the absence of direct forms of violence $(17,69)$.

\section{Discussion}

This study contends that, in order to educate for peace, it is important to teach students to recognize violence. Although the Plan de Estudios does mention several themes that are related to structural violence, there is a significant lack of statements regarding direct and cultural violence. As the country has been experiencing high levels of violence in relation to narcotrafficking and gangs, as well as gender and domestic violence as discussed in the Introduction, there is no shortage of examples for recognizing violence in Mexican society. There are multiple reasons why these topics might not be discussed in the curriculum, and yet, if the next generation of students is to help solve these problems, they need to be made aware of 'negative knowledge' in a formal mode of study in order to help develop solutions (Harris and Morrison, 2013: 35).

The Plan de Estudios gives very little specific information about how to solve problems generally or methods of transforming conflict nonviolently. The 'core role of nonviolence in peace education is rooted in [the] conception of human goodness, such that individuals find their true identity and expression through adhering to nonviolence' (Synott, 2005: 9). Nonviolence as a foundation of humanity is not clearly established in the Plan de Estudios.

Despite the number of references to dialogue, the curriculum does not formally define dialogue or clarify effective dialogue practice. The introduction to the curriculum states:

Another characteristic of the Study Plan is its orientation towards the development of attitudes, practices and values sustained in the principles of democracy: respect for the law, equality, freedom with responsibility, participation, dialogue and the desire for agreements/accords, tolerance, inclusion and plurality. (26)

Although there are many words here that are often associated with a culture of peace, how to develop these attitudes, practices and values is left unexplored. This is similar to the sole mention of negotiation, which lacks functional context or operational relevancy.

Although collaboration and dialogue are mentioned multiple times, these terms are left undefined, and processes for effective collaboration and dialogue - methods that involve practicing techniques - are left unexplored. Negotiation reconciliatory discussion - similarly to collaboration and dialogue, is left undefined in the curriculum. As Harris (2004: 6) notes, 'peace educators cannot eliminate conflict, but they can provide students with valuable skills in managing conflict'; the prescription of collaboration, dialogue and negotiation in Plan de Estudios for the 
actual transformation of conflict would be beneficial. Furthermore, since the Plan de Estudios is supportive of collaboration with Indigenous communities, it might be useful to include some traditional Indigenous methods of nonviolent conflict transformation from Mexico in the next curriculum in an effort to locally root methods of dealing with conflict that are not directly, structurally or culturally violent.

Human rights are referred to in Section 2 of the curriculum, 'Competencies for life':

For their development it is required: to decide and act with critical judgement in the presence of societal and cultural values and norms; to proceed in favour of democracy, freedom, peace, respect for legality and human rights; to participate taking into account the social implications of the use of technology, combat discrimination and racism, and become aware of belonging to their culture, their country and the world. (38)

Although passages such as this recognize the need for human rights to combat racism, it is without a framework for development or details of what that might look like in a school context.

The incorporation of Indigenous conflict resolution methods is just one example of how the inclusion of Indigenous peoples' world views could be added to Plan de Estudios. Where multiple references to social justice (in relation to diversity and collaboration with Indigenous communities) are important, specific strategies for building relationships with people who have historically been left out of the conversation are integral to the success of moving towards positive peace. Harris and Morrison (2013: $14,36)$ maintain that 'peace cannot be separated from [the] idea of justice', and that building peace requires 'a sense of responsibility for self and others'. With this in mind, future curricula can include content related to ideas of fairness, human rights, and the responsibilities that inhere with groups and individuals to exercise their rights (ensured by the government) and champion the universality of such rights to all humans as inalienable. Such considerations interconnect with statements relating to well-being that ignore how well-being is deeply interconnected to notions of race, gender or sexuality. The recognition that a student's race, gender or sexuality might have a significant impact on their life experiences, and therefore on their well-being, is disregarded.

Resilience - the ability to cope with disaster when it happens - and prevention - the chance to stop violence before it starts - interrelate, in that when violence is not prevented, the capacity to overcome violence is a desirable outcome. In Plan de Estudios, bullying prevention is recognized as a desirable outcome for students, and risk is presented as an opportunity to be overcome. As Bickmore (2011: 643) states:

A number of scholars state categorically (though not always with robust evidence) that negotiation-based approaches are ineffective or even harmful as responses to bullying and harassment ... Yet other approaches to dialogic problem solving - such as class meetings, group conferencing, and other circle processes conducted by skilled and equity-conscious facilitators - hold substantial promise as part of a comprehensive response to harassment problems.

Such findings indicate that preventing violence (bullying) requires a comprehensive approach that begins with the recognition that such instances of violence occur, and that they are undesirable. In addition, the ability of students to gain resilience can relate to feelings of interpersonal support in peer groups, concerns addressed more robustly through dialogic processes that in turn work to prevent future violence. 
The Plan de Estudios recognizes that gender hierarchies exist, as does racial discrimination, but there is no discussion of how gender and race can be approached by students, or specific recognition of how those gender and race inequalities manifest in Mexican society. Future curriculum changes could include gender and race (both expectations and experiences) as more meaningful features of understanding, as both are intrinsically related to experiences of violence.

Of concern for this study of the Plan de Estudios is the minimal content related to peace zone, peace bond and eco mind. Creating a safe space for students (peace zone), free from violence, and where they can interact positively with others and their environment, is integral to the development of positive peace in Mexican schools. Harris (2004: 16) has written that 'through education people can develop certain thoughts and dispositions that lead to peaceful behavior' such as kindness. This analysis finds that there is ample opportunity for future iterations of the Mexican national curriculum to incorporate matter that includes greater content related to kindness and empathy (peace bond). Further, as climate change starts to have a greater impact on Mexico and the world, this relationship between humanity and the Earth will be of increasing importance. As Bajaj (2008: 21) reminds us, 'it is not sufficient just to talk about military security, as in protecting the citizens of a country from a foreign threat, but it is also necessary to promote a concept of peace based upon ecological security'. The next generation of students in Mexico will benefit from content that envisions them as individuals, community members and global citizens of a healthy Earth (Harris and Morrison, 2013).

Finally, despite several passages coded as link mind (evidence of the concept of interconnectivity) the curriculum does not ascertain the importance of perceiving life as a web of interlinks, that 'Understanding human interconnectedness with the natural world is vital for developing students' ability to make decisions regarding environmental issues and to inspire action for overcoming those challenges in order to sustain a healthy Earth' (Shulsky et al., 2017: 58), and that our conceptualization of ourselves as self, other, friend or enemy relate to ways of thinking about both rights (social justice) and responsibilities (well-being) in society. The interconnections between our spaces, actions and behaviours may present an opportunity for future learners to 'connect' to this conceptualization in a more robust manner.

\section{Conclusions}

This mixed methods analysis utilized directive (qualitative) and summative (quantitative) content analysis to scrutinize the basic national curriculum statement of Mexico - the Plan de Estudios Educación Básica, 2011 (Secretaría de Educación Pública, 2015). It investigated the curricular statement to establish whether three elements common in peace education programmes materialize: recognizing violence (direct, structural or cultural); transforming conflict nonviolently; and contributing to nine facets of positive peace. This analysis found some evidence of reference to structural violence, minimal evidence of reference to cultural violence and only one reference to direct violence. It found evidence of three tools for transforming conflict nonviolently (collaboration, dialogue and negotiation) and, despite some passages that indicate the importance of equality, well-being and interconnectivity, there were limited passages that communicate the importance of building resilience, being aware of gender, behaving with kindness or preventing violence, only two references to safety, and only one reference to harmonious living between humanity and nature. If the Plan de Estudios were to contribute to the SDGs quality education (4), gender 
equality (5), reduced inequalities (10), responsible consumption and production (12) and peace, justice and strong institutions (16), as well as the specific targets mentioned here, those areas could be strengthened.

The PECA Project considers it possible and desirable to investigate non-peace education(s) for peace education substance. This study of the national curriclum of Mexico unearths abundant room to incorporate additional content in the curriculum that contributes to the aims and objectives of peace education. In general, there are opportunities to create learning platforms that are more inclusive of environmental consideration (eco mind), engage more meaningfully with notions of the rights of students to live in violence-free spaces (peace zone), contribute to the creation of practices that result in fostering coping skills (resilience), strengthen positive and warm relationships (peace bond), recognize how difference does not mean a lack of equality (gender mind, social justice) and recognize violence in order to prevent it.

\section{Acknowledgements}

The authors thank the University of Otago for their support that allowed them to conduct this analysis.

\section{Notes on the contributors}

Heather Kertyzia, PhD, is the Head of the Peace and Conflict Studies Department at the University for Peace in Costa Rica. Her areas of investigation and teaching include peace education, gender and peacebuilding and participatory research methods.

Katerina Standish, PhD, is the Deputy Director of the National Centre for Peace and Conflict Studies at the University of Otago, New Zealand. Her areas of research expertise and writing for publication include peace education, curricular analysis, nonviolence, life-ending acts, and cultural violence and hope.

\section{References}

Abrego Franco, M.G. (2010) 'La situación de la educación para la paz en México en la actualidad'. Espacios Públicos, 13 (27), 149-64.

Amador Hernández, J.C. (2008) La evaluación y el diseño de políticas educativas en México (Documento de Trabajo 35). Ciudad de México: Centro de Estudios Sociales y de Opinión Pública.

Bajaj, M. (ed.) (2008) Encyclopedia of Peace Education. Charlotte, NC: Information Age Publishing.

Bar-On, D. (2010) 'Storytelling and multiple narratives in conflict situations: From the TRT Group in the German-Jewish context to the dual-narrative approach of PRIME'. In Salomon, G. and Cairns, E. (eds) Handbook on Peace Education. New York: Psychology Press, 199-212.

BBC News (2015) 'Mexico insists 43 missing students are dead'. BBC News, 28 January. Online. www.bbc.com/news/world-latin-america-31013491 (accessed 13 February 2018).

Bickmore, K. (2011) 'Policies and programming for safer schools: Are "anti-bullying" approaches impeding education for peacebuilding?'. Educational Policy, 25 (4), 648-87.

Boulding, E. (2000) Cultures of Peace: The hidden side of history. Syracuse, NY: Syracuse University Press.

Carter, C.C. and Vandeyar, S. (2009) 'Teacher preparation for peace education in South Africa and the United States: Maintaining commitment, courage, and compassion'. In McGlynn, C., Zembylas, M., Bekerman, Z. and Gallagher, T. (eds) Peace Education in Conflict and Post-Conflict Societies: Comparative perspectives. New York: Palgrave Macmillan, 247-61.

Clarke-Habibi, S. (2005) 'Transforming worldviews: The case of Education for Peace in Bosnia and Herzegovina'. Journal of Transformative Education, 3 (1), 33-56. 
Danesh, H.B. (2010) 'Unity-based peace education: Education for Peace Program in Bosnia and Herzegovina: A chronological case study'. In Salomon, G. and Cairns, E. (eds) Handbook on Peace Education. New York: Psychology Press, 253-68.

Duffy, T. (2000) 'Peace education in a divided society: Creating a culture of peace in Northern Ireland'. Prospects, 30 (1), 15-29.

Fisas, V. (2011) Educar para una Cultura de Paz (Quaderns de Construcció de Pau 20). Barcelona: Escola de Cultura de Pau.

Fountain, S. (1999) Peace Education in UNICEF (Working Paper). New York: United Nations Children's Fund Programme Publications. Online. https://tinyurl.com/y6nc57hr (accessed 28 February 2019).

Galtung, J. (1990) 'Cultural violence'. Journal of Peace Research, 27 (3), 291-305.

Galtung, J. (1996) Peace by Peaceful Means: Peace and conflict, development and civilization. London: SAGE Publications.

Gómez Collado, M.E. (2010) 'La Educación para la Paz aplicada a la Tutoría Académica en la Facultad de Ciencias Políticas y Sociales de la Universidad Autónoma del Estado de México'. Revista de Paz y Conflictos, 3, 123-39.

Harber, C. and Sakade, N. (2009) 'Schooling for violence and peace: How does peace education differ from "normal" schooling?' Journal of Peace Education, 6 (2), 171-87.

Harris, I.M. (2004) 'Peace education theory'. Journal of Peace Education, 1 (1), 5-20.

Harris, I.M. and Morrison, M.L. (2013) Peace Education. 3rd ed. Jefferson, NC: McFarland and Company.

Hsieh, H.-F. and Shannon, S.E. (2005) 'Three approaches to qualitative content analysis'. Qualitative Health Research, 15 (9), 1277-88.

Krippendorff, K. (2004) Content Analysis: An introduction to its methodology. 2nd ed. Thousand Oaks, CA: SAGE Publications.

Leedy, P.D. and Ormrod, J.E. (2001) Practical Research: Planning and design. 7th ed. Upper Saddle River, NJ: Merrill Prentice Hall.

Lozano Garza, N. (2015) 'Education for Peace in the Mexican context'. Canadian Journal of Latin American and Caribbean Studies, 40 (2), 200-21.

Maastricht Global Education Declaration (2002) European Strategy Framework for Improving and Increasing Global Education in Europe to the Year 2015: Europe-Wide Global Education Congress, Maastricht, The Netherlands, November 15th-17th 2002. Online. https://rm.coe. int/168070e540 (accessed 15 February 2018).

Magaloni, B. (2012) The Impact of Violence on Human Capital: Findings from schools in Mexico (Program on Poverty and Governance Research Report). Stanford: Stanford University.

Márquez-Padilla, F., Pérez-Arce, F. and Rodríguez-Castelán, C. (2015) The (Non-) Effect of Violence on Education: Evidence from the "war on drugs" in Mexico. Online. www.rand.org/pubs/ working_papers/WR1082.html (accessed 14 April 2019).

Mertens, D.M. (2010) Research and Evaluation in Education and Psychology: Integrating diversity with quantitative, qualitative, and mixed methods. 3rd ed. Thousand Oaks, CA: SAGE Publications.

Ocejo, V. and Hernández Romano, A.P. (eds) (2016) Derechos Humanos y Educación para la Paz. Ciudad de México: Universidad Iberoamericana.

Perez, J.C. (2014) 'Mexico missing students: Looking for Iguala mass graves'. BBC News, 8 December. Online. www.bbc.com/news/world-latin-america-30316124 (accessed 13 February 2018).

Ruiz León, A. (2013) Estado de la Educación para la Paz en México. Chihuahua: Instituto Tecnológico y de Estudios Superiores de Monterrey.

Salomon, G. (2004) 'Does peace education make a difference in the context of an intractable conflict?'. Peace and Conflict: Journal of Peace Psychology, 10 (3), 257-74.

Secretaría de Educación Pública (2015) Plan de Estudios: Educación Básica en México. Online. www.gob.mx/sep/documentos/plan-de-estudios-educacion-basica-en-mexico-2011 (accessed 14 April 2019).

Shulsky, D.D., Baker, S.F., Chvala, T. and Willis, J.M. (2017) 'Cultivating layered literacies: Developing the global child to become tomorrow's global citizen'. International Journal of Development Education and Global Learning, 9 (1), 49-63.

Standish, K. (2015) 'Looking for peace in the Australian national curricula'. Peace and Conflict Studies, 22 (2), Article 5, 177-203.

Standish, K. (2016) 'Looking for peace in national curriculum: The PECA Project in New Zealand'. Journal of Peace Education, 13 (1), 18-40. 
Standish, K. and Joyce, J. (2016) 'Looking for peace in the national curriculum of Scotland'. Peace Research: The Canadian Journal of Peace and Conflict Studies, 48 (1-2), 67-90.

Standish, K. and Kertyzia, H. (2014) 'Looking for peace in the English national curricula'. Journal for Peace and Justice Studies, 24 (2), 73-99.

Standish, K. and Nygren T. (2018) 'Looking for peace in the Swedish national curricula'. Nordic Journal of Studies in Educational Policy, 4 (2), 92-106.

Standish, K. and Talahma, R. (2016) 'Looking for peace in the national curricula of the Kingdom of Saudi Arabia'. Peace and Conflict Studies, 23 (2), Article 2, 1-30.

Synott, J. (2005) 'Peace education as an educational paradigm: Review of a changing field using an old measure'. Journal of Peace Education, 2 (1), 3-16.

\section{Appendix: Spanish translations}

\begin{tabular}{|c|c|c|c|}
\hline $\begin{array}{l}\text { Page number } \\
\text { where referred } \\
\text { to in this } \\
\text { document }\end{array}$ & $\begin{array}{l}\text { Page number } \\
\text { in Plan de } \\
\text { Estudios }\end{array}$ & Spanish original & English translation \\
\hline 11 & 36 & $\begin{array}{l}\text { la prevención de la } \\
\text { violencia escolar }\end{array}$ & $\begin{array}{l}\text { prevention of school } \\
\text { violence (bullying) }\end{array}$ \\
\hline 11 & 35 & $\begin{array}{l}\text { La educación es un } \\
\text { derecho fundamental } \\
\text { y una estrategia para } \\
\text { ampliar las oportunidades, } \\
\text { instrumentar las relaciones } \\
\text { interculturales, reducir } \\
\text { las desigualdades entre } \\
\text { grupos sociales, cerrar } \\
\text { brechas e impulsar la } \\
\text { equidad }\end{array}$ & $\begin{array}{l}\text { Education is a fundamental } \\
\text { right and a strategy to } \\
\text { amplify opportunities, } \\
\text { orchestrate intercultural } \\
\text { relations, reduce } \\
\text { inequalities between social } \\
\text { groups, close gaps and } \\
\text { drive equity }\end{array}$ \\
\hline 11 & 39 & $\begin{array}{l}\text { combatir la discriminación } \\
\text { y el racismo }\end{array}$ & $\begin{array}{l}\text { fight against discrimination } \\
\text { and racism }\end{array}$ \\
\hline 12 & 18 & $\begin{array}{l}\text { constituya redes } \\
\text { académicas de } \\
\text { aprendizaje en la que } \\
\text { todos los integrantes de } \\
\text { la comunidad escolar } \\
\text { participen }\end{array}$ & $\begin{array}{l}\text { establish academic } \\
\text { learning networks in } \\
\text { which all the members } \\
\text { of the school community } \\
\text { participate }\end{array}$ \\
\hline 12 & 69 & $\begin{array}{l}\text { La Reforma Integral de } \\
\text { la Educación Básica } \\
\text { (RIEB) requiere, para su } \\
\text { efectiva aplicación que } \\
\text { los colectivos escolares } \\
\text { desarrollen nuevas formas } \\
\text { de relación, colaboración y } \\
\text { organización, ya que cada } \\
\text { escuela representa en si } \\
\text { misma un espacio para el } \\
\text { aprendizaje y, al mismo } \\
\text { tiempo, forma parte de } \\
\text { una red de gestión de } \\
\text { aprendizajes de docentes, } \\
\text { alumnos y padres de } \\
\text { familia, entre otros actores } \\
\text { de la comunidad }\end{array}$ & $\begin{array}{l}\text { The Comprehensive } \\
\text { Reform of Basic Education } \\
\text { (CRBE) requires for its } \\
\text { effective application, that } \\
\text { the school collectives } \\
\text { develop new ways of } \\
\text { relating, collaborating and } \\
\text { organizing, since each } \\
\text { school represents in itself a } \\
\text { space for learning and, at } \\
\text { the same time, forms part } \\
\text { of a network of learning } \\
\text { governance comprised of } \\
\text { teachers, students, and } \\
\text { parents, among the other } \\
\text { community actors }\end{array}$ \\
\hline
\end{tabular}




\begin{tabular}{|c|c|c|c|}
\hline $\begin{array}{l}\text { Page number } \\
\text { where referred } \\
\text { to in this } \\
\text { document }\end{array}$ & $\begin{array}{l}\text { Page number } \\
\text { in Plan de } \\
\text { Estudios }\end{array}$ & Spanish original & English translation \\
\hline 12 & 38 & $\begin{array}{l}\text { Competencias para la } \\
\text { convivencia- negociar con } \\
\text { otros }\end{array}$ & $\begin{array}{l}\text { is included in } \\
\text { competencies for } \\
\text { coexistence as negotiate } \\
\text { with others }\end{array}$ \\
\hline 13 & 17 & $\begin{array}{l}\text { Favorecer la educación } \\
\text { inclusiva, en particular } \\
\text { las expresiones locales, } \\
\text { la pluralidad lingüística } \\
\text { y cultural del país y a } \\
\text { los estudiantes con } \\
\text { necesidades educativas } \\
\text { especiales, con o sin } \\
\text { discapacidad }\end{array}$ & $\begin{array}{l}\text { favour inclusive education, } \\
\text { in particular local } \\
\text { expression, the linguistic } \\
\text { and cultural plurality of the } \\
\text { country, and students with } \\
\text { special educational needs, } \\
\text { with or without disabilities }\end{array}$ \\
\hline 13 & 11 & $\begin{array}{l}\text { La sociedad mexicana en } \\
\text { el siglo XXI es resultado de } \\
\text { la fusión o convergencia } \\
\text { de diversas culturas, todas } \\
\text { valiosas y esenciales }\end{array}$ & $\begin{array}{l}\text { Mexican society in the } \\
\text { twenty-first century is the } \\
\text { result of the fusion or } \\
\text { convergence of diverse } \\
\text { cultures, all valuable and } \\
\text { essential }\end{array}$ \\
\hline 14 & 35 & $\begin{array}{l}\text { Educación Básica le } \\
\text { corresponde crear } \\
\text { escenarios basados en } \\
\text { los derechos humanos y } \\
\text { el respeto a la dignidad } \\
\text { humana }\end{array}$ & $\begin{array}{l}\text { basic education is } \\
\text { responsible for creating } \\
\text { scenarios based in human } \\
\text { rights and respect for } \\
\text { human dignity }\end{array}$ \\
\hline 14 & 23 & $\begin{array}{l}\text { promoción de la salud (la } \\
\text { nutrición y prevención de } \\
\text { adicciones, etcétera) }\end{array}$ & $\begin{array}{l}\text { health promotion (nutrition } \\
\text { and the prevention of } \\
\text { addictions, et cetera) }\end{array}$ \\
\hline 14 & 51 & $\begin{array}{l}\text { la prevención de } \\
\text { quemaduras y otros } \\
\text { accidentes }\end{array}$ & $\begin{array}{l}\text { the prevention of burns } \\
\text { and other accidents }\end{array}$ \\
\hline 14 & 54 & $\begin{array}{l}\text { construcción de la } \\
\text { identidad personal y de las } \\
\text { competencias emocionales } \\
\text { y sociales }\end{array}$ & $\begin{array}{l}\text { the construction of } \\
\text { personal identity and } \\
\text { of social and emotional } \\
\text { competencies }\end{array}$ \\
\hline 14 & 10 & $\begin{array}{l}\text { un mundo cada vez más } \\
\text { interrelacionado }\end{array}$ & $\begin{array}{l}\text { a world that is increasingly } \\
\text { more interrelated }\end{array}$ \\
\hline 14 & 17 & $\begin{array}{l}\text { una escuela de la } \\
\text { comunidad donde } \\
\text { todos crezcan individual } \\
\text { y colectivamente: } \\
\text { estudiantes, docentes, } \\
\text { madres y padres de familia }\end{array}$ & $\begin{array}{l}\text { a school of the community } \\
\text { where everyone } \\
\text { grows individually and } \\
\text { collectively: students, } \\
\text { teachers, parents }\end{array}$ \\
\hline 14 & 9 & $\begin{array}{l}\text { oportunidades para } \\
\text { enfrentar con mayor éxito } \\
\text { los desafíos del presente y } \\
\text { el futuro }\end{array}$ & $\begin{array}{l}\text { opportunities to face } \\
\text { with better success the } \\
\text { challenges of the present } \\
\text { and future }\end{array}$ \\
\hline 14 & 47 & $\begin{array}{l}\text { son practicas que rechazan } \\
\text { la discriminación }\end{array}$ & $\begin{array}{l}\text { practices that reject } \\
\text { discrimination }\end{array}$ \\
\hline
\end{tabular}




\begin{tabular}{|c|c|c|c|}
\hline $\begin{array}{l}\text { Page number } \\
\text { where referred } \\
\text { to in this } \\
\text { document }\end{array}$ & $\begin{array}{l}\text { Page number } \\
\text { in Plan de } \\
\text { Estudios }\end{array}$ & Spanish original & English translation \\
\hline 15 & 36 & $\begin{array}{l}\text { es conveniente que las } \\
\text { normas del salón de clases } \\
\text { y de la escuela se revisan } \\
\text { periódicamente, para } \\
\text { determinar cuales son } \\
\text { funcionales, no lesionan a } \\
\text { nadie y apoyan el trabajo } \\
\text { conjunto }\end{array}$ & $\begin{array}{l}\text { it is advisable that the rules } \\
\text { of the classrooms and } \\
\text { of the school are revised } \\
\text { periodically, in order to } \\
\text { determine which are } \\
\text { functional, do not harm } \\
\text { anyone and support joint } \\
\text { work }\end{array}$ \\
\hline 15 & 13 & $\begin{array}{l}\text { cada una de las acciones } \\
\text { y planteamientos } \\
\text { curriculares encaminados } \\
\text { a consolidar la equidad de } \\
\text { genero }\end{array}$ & $\begin{array}{l}\text { each one of the actions } \\
\text { and curricular plans is } \\
\text { directed at strengthening } \\
\text { gender equity }\end{array}$ \\
\hline 15 & 57 & $\begin{array}{l}\text { promover el respeto entre } \\
\text { géneros }\end{array}$ & $\begin{array}{l}\text { the promotion of respect } \\
\text { between genders }\end{array}$ \\
\hline 15 & 34 & $\begin{array}{l}\text { parámetros relativos } \\
\text { a jerarquías sociales o } \\
\text { genero }\end{array}$ & $\begin{array}{l}\text { parameters related } \\
\text { to social or gender } \\
\text { hierarchies }\end{array}$ \\
\hline 15 & 38 & $\begin{array}{l}\text { empatía, relacionarse } \\
\text { armónicamente con otros y } \\
\text { la naturaleza }\end{array}$ & $\begin{array}{l}\text { empathy to relate } \\
\text { harmoniously with others } \\
\text { and nature }\end{array}$ \\
\hline 15 & 38 & $\begin{array}{l}\text { relacionarse } \\
\text { armónicamente con otros y } \\
\text { la natura }\end{array}$ & $\begin{array}{l}\text { relating harmoniously with } \\
\text { others and nature }\end{array}$ \\
\hline 16 & 26 & $\begin{array}{l}\text { Otra característica del } \\
\text { Plan de estudios es su } \\
\text { orientación hacia el } \\
\text { desarrollo de actitudes, } \\
\text { practicas y valores } \\
\text { sustentados en los } \\
\text { principio de la democracia: } \\
\text { el respeto a la legalidad, } \\
\text { la igualdad, la libertad } \\
\text { con responsabilidad, la } \\
\text { participación, el diálogo y } \\
\text { la búsqueda de acuerdos; } \\
\text { la tolerancia la inclusión y } \\
\text { la pluralidad }\end{array}$ & $\begin{array}{l}\text { Another characteristic } \\
\text { of the Study Plan is its } \\
\text { orientation towards the } \\
\text { development of attitudes, } \\
\text { practices and values } \\
\text { sustained in the principles } \\
\text { of democracy: respect for } \\
\text { the law, equality, freedom } \\
\text { with responsibility, } \\
\text { participation, dialogue and } \\
\text { the desire for agreements/ } \\
\text { accords, tolerance, } \\
\text { inclusion and plurality }\end{array}$ \\
\hline
\end{tabular}




\begin{tabular}{|c|c|c|c|}
\hline $\begin{array}{l}\text { Page number } \\
\text { where referred } \\
\text { to in this } \\
\text { document }\end{array}$ & $\begin{array}{l}\text { Page number } \\
\text { in Plan de } \\
\text { Estudios }\end{array}$ & Spanish original & English translation \\
\hline 17 & $38-39$ & $\begin{array}{l}\text { Para su desarrollo se } \\
\text { requiere: decidir y actuar } \\
\text { con juicio critico frente a } \\
\text { los valores y las normas } \\
\text { sociales y culturales; } \\
\text { proceder a favor de la } \\
\text { democracia, la libertad, } \\
\text { la paz, el respeto a la } \\
\text { legalidad y a los derechos } \\
\text { humanos; participar } \\
\text { tomando en cuenta las } \\
\text { implicaciones sociales } \\
\text { del uso de la tecnología; } \\
\text { combatir la discriminación } \\
\text { y el racismo, y conciencia } \\
\text { de pertenencia a su } \\
\text { cultura, a su país y al } \\
\text { mundo }\end{array}$ & $\begin{array}{l}\text { For their development it } \\
\text { is required: to decide and } \\
\text { act with critical judgement } \\
\text { in the presence of the } \\
\text { societal and cultural values } \\
\text { and norms; to proceed } \\
\text { in favour of democracy, } \\
\text { freedom, peace, respect } \\
\text { for legality and human } \\
\text { rights; to participate taking } \\
\text { into account the social } \\
\text { implications of the use } \\
\text { of technology, combat } \\
\text { discrimination and racism, } \\
\text { and become aware of } \\
\text { belonging to their culture, } \\
\text { their country and the world }\end{array}$ \\
\hline
\end{tabular}

